\title{
Johan Heyns and the class of ' 51 - prolegomena to a story of people who got hurt
}

C Landman

\section{ABSTRACT}

Johan Heyns and the class of '51 - prolegomena to a story of people who got hurt

This article consists of three parts. In the first part a story is told of Johan Heyns and some of the men who shared with him the final year of theological training at the University of Pretoria in 1951. In the second part prolegomena to the telling of a new story of Johan Heyns are explained. Finally this new story is told by using the voices of six people - students, colleagues and family - who interrupt each other's voice on Johan Heyns, thereby undermining the popular ideal amongst local church historians that religion biography can and should recreate a complete and consistent image of a person's (moral) reality.

\section{JOHAN HEYNS AND THE CLASS OF '51}

The class who finished their third year of training as ministers of the Dutch Reformed Church at the University of Pretoria in 1951 consisted of fifteen men of whom nine were to become professors in Theology1. They became known to posterity either because of their conservative or their liberal attitude towards the politics of the day.

Of them Nico Smith, former right wing missionary who abandoned his post as professor at Stellenbosch to identify with the black liberation struggle as an ordinary minister, eventually ventured the furthest to the left; Willie Jonker and Johan Heyns claimed conversion away from their status quo but detested being called "liberal" by their contemporaries. The reason for this may be that Tobie Hanekom's definition of "liberalism" 2 was authoritative in the Dutch Reformed Church at that time. According to this definition a "liberal" is somebody who acknowledges the natural equality of all people and rejects forms of hierarchical authority. Jonker and Heyns, while being professors of Theology at Stellenbosch and Pretoria University respectively, for reasons pertaining to their position in the church, preferred not to be called liberal in this sense. 
Carel Boshoff, on the other hand, overtly joined the ranks of right wing Afrikaners after his retirement as professor in Missiology at the University of Pretoria and showed no resistance to being called "conservative". Within this same range of attitudes can be found F A H van Staden and H S Theron who became professors at the seminary of the ultra-conservative Afrikaanse Protestantse Kerk (Afrikaans Protestant Church). This church broke away from the Dutch Reformed Church on political issues in 1987 during Johan Heyns' term as general moderator.

Murray Hofmeyer and Deon de Villiers both became professors at Witsieshoek, one of the black theological training seminaries of the Dutch Reformed Church. A commitment to mission amongst blacks which might have been based on a covert belief in the segragation of politics and piety, kept both these men from deliberately building up a public profile of politically outspoken churchmen.

Finally to be mentioned amongst the men of ' 51 who became professors of Theology, is Murray Janson. Janson has eventually chosen to take on an apolitical image in order to build up a reputation as a pastoral counselor to local white middle-class women.

The class of ' 51 commenced with their theological degree in 1949. This was the year after the Nationalist Party had come to power in South Africa. Political change as well as political discourse were in the air. The theological training to which the men under discussion were exposed, was, however, conspicuously apolitical. Theology was presented to them without any specific social or political context. Discussions amongst students featured the punctuation of the Apostles' Creed and other acontextual dogmatic issues ${ }^{3}$.

The class of '49/'51 came from the same rural Afrikaans background and received the same theological training. Unknowingly they could have had the same ambition which was to win the favour of their religious society and their church and to climb the ecclesiastical ladder. However, forty odd years later (in the 1990s) we find them scattered all over the political arena. Nico Smith has embarrassed the Dutch Reformed Church by accusing the white church at the Rustenburg Conference of showing a greater willingness towards brotherhood with other churches than towards sisterhood with their own "daughter" churches. Of the two reluctant liberals, Willie Jonker confessed at Rustenburg that his church had been guilty of apartheid and not long after that we find Johan Heyns murdered, popular belief attributing the murder to Heyns' liberal connotations. We also find that Nico Smith established a multi-racial congregation in the middle of a traditionally white group area in Pretoria and that Carel Boshoff, on 
the other hand, established a white homeland, Orania, in the middle of the country.

How then did it happen that men who had received the same acontextual theological training with the same pietistic trimmings, in later years developed opposing political attitudes? One reason may be that they were converted by (white) men of different political convictions while they were engaged in doctoral studies in Europe. However, even the leftist amongst them were converted to the cause of black liberation not by blacks, but by white men, Nico Smith by the Germans (especially Karl Barth) and Jonker and Heyns by the Dutch. The conservatives amongst them were influenced by the heritage of Abraham Kuyper, a Dutch theologian turned statesman who believed in the sovereignty of nations in governing themselves.

Because both the "liberal" and the "conservative" members of the class of ' 51 were white men converted to a political stance of other white men, their position were not that opposing after all. Except for Nico Smith who became part of the black church's hierarchy, the "liberals", Heyns and Jonker, remained within the official and privileged structures of the white church. Although he was accused of liberal tendencies by a major part of his church, Heyns acted as a confidant of the Nationalist Government and served the Afrikaner nation as leader of prominent cultural organisations such as the FAK (Federation of Afrikaans Cultural Organisations).

The "liberals" and the "conservatives" of the class of '51 then had much in common. All of them, for instance, remained loyal to the patriarchy of the church although it has to be mentioned that Johan Heyns supported women's ordination at the Synod of 1990. While fighting other white men on commissions, on disciplinary committees and in synods, they remained ignorant of the beliefs, the "theology" of the women in the suburban houses and the blacks in the backyards of their congregations. While fighting each other on the right principles in handling blacks and women, they seldomly thought of God outside of the traditional Reformed concept of God and allowed little space for women and blacks to rename God.

The men of '51, albeit unconsciously, saw and probably still see themselves as amongst the main role players in South African church history because of their position in the church and their decision-making role in commissions and synods. It is no longer the ideal of religion biography to write the stories of religious leaders as the rocks on whose constantly correct decisions society rests. A theme unexplored in the story of the leaders of the Reformed tradition in South Africa is, for instance, the role hurt- 
ing plays in religion discourse. The "liberals" and "conservatives" of the class of ' 51 got badly hurt by one another and amongst themselves. The reason for exploring this theme here is not the suspicion that men, in this case religious men in high offices, have fragile egos, but to show that men have emotions which they are probably not allowed to acknowledge on commissions and in synods.

Women historians today do not regard commissions and synods and the people of high office who man them to be the main elements constituting history. They do not regard hierarchical positioning as the main element generating a story, not even that of a person in high office. They regard history as a story of people and their experiences. I shall therefore tell a story about Johan Heyns as a person who, in his daily relationships, stood at both ends of a hurting game.

\section{PROLEGOMENA TO A STORY OF PEOPLE IN THE HURT- ING GAME}

The objective of the last and main part of this article, to which this part acts as a methodological introduction, is to write a short story of Johan Heyns based on the stories of six people. These people are Renée SpamerHeyns (wife) ${ }^{4}$, Cornel du Toit (student and colleague) ${ }^{5}$, Willie Jonker (class of $\left.{ }^{51}\right)^{6}$, Willem Kleynhans (political scientist) ${ }^{7}$ and Nico Smith (class of '51) ${ }^{8}$. Their stories concentrate on Johan Heyns as a person who was on both the receiving and the distributing end of the hurting game.

In order to tell this story, I intend to undermine the modernist urge of the researcher to situate herself in terms of gender, class and race. Acknowledging God's right to predestination, this researcher will not predestine herself to telling her story as that of a white, middle-class, Afrikaansspeaking female. Also, she does not want to predict the outcome of her story introductorily by situating her oral sources. Of course their stories of Johan Heyns reflect the stories of their own lives; of course they told their stories to meet the needs of this researcher - needs they probably experienced not to be on a traditional and pietistic level. For this story the researcher wants to interrupt her own voice as researcher ${ }^{9}$ and to use the voices of her sources to interrupt one another in order to highlight the unexpected and the ironical in the story of a person who was known for his dogmatic predictability and moral consistency.

This does not mean that this story of interrupting voices will be a fragmented story, since that would be narratively unpleasing. It simply means that in this story the division between personal and public will be 
undermined and the story will be presented publicly not as representing personal voices, but as a piece of literature, a story with which the public might identify. This furthermore means that the division between theological meta-language and literary language will be undermined ${ }^{10}$ in order to tell a story in which Johan Heyns's literary status will be taken seriously. It is not Johan Heyns's status as an hierarchical achiever or a dogmatic opinion-former which is on the table here, but his status as a storygenerator. People have been telling stories about Johan Heyns. Some of these stories they have told to this researcher and some they have told amongst themselves. People told stories about Jesus too. And $\mathrm{He}$ too told stories to the people - parables - which the people interpreted morally. The moral focussing of my story of Johan Heyns will be placed solely in the hands of the reader.

\section{TELLING THE HURTING STORY 11}

During the 1930's white male adolescence on a farm in the Orange Free State meant that a decision must be made to become either a farmer, a teacher or a minister of religion. The academic achievers amongst them, which included the young Johan Heyns, were predestined by their families, and especially by their mothers, for the ministry.

Heyns underwent his secondary and tertiary training at institutions in Potchefstroom with the intellectual security offered by lecturers such as the philosopher Herman Stoker and by paradigms of thoughts such as a Calvinist form of Christian science ("Christelike wetenskap"). The christianisation of science at Potchefstroom presupposes that science can and should be practised from a Calvinist world view and that theology was a science in this sense.

When Heyns went to Pretoria University for his theological degree in 1949, these securities were confirmed and extended by his new academic environment, albeit under different theological names. At Pretoria Heyns was reinformed about the know ability of God, a belief which was presented as having originated in its modern(ist) form with Karl Barth. Heyns' Pretoria lecturers were, of course, more keen on divine revelation than on science based on human subjectivity and initially Heyns clashed with professor A B du Preez on this issue. Furthermore Willie Jonker, one of his classmates, publicly placed his own idea of mystical ways of knowing God and belonging to the universal church against Heyns' scientific approach to the personal God. And that hurt too.

Heyns eventually learnt to combine revelation and science, that is, to put God to words with dogmatic certainty. His studies in Europe under G 
C Berkouwer (1951-2) played no small part in this. In the Western Europe of the 1950s male rationality was successful in transforming theology into a science in which correct thinking was, through the extended use of metalanguage, accurately distinguishable from incorrect thought.

The accurate naming of God in meta-language did not hurt Heyns until he was called to his first congregation in South Africa. Heyns, who first turned doctor (1953) and then minister (1954), was called to Ysterplaat where the congregation simply did not understand what he was trying to communicate. And that hurt him. Eventually, however, Heyns became a popular minister in this congregation, simply because the people sensed that he loved them. Not a training in strictly divine matters, not years of academic exercises in supra-human language could kill his relationships with people and the personal charm he extended to them.

However, Heyns did not come back from Europe only with a doctorate and expertise in white male meta-language. He came back from Europe with experiences which, incidentally, concerned a black man and a woman. One day, in a Reformed congregation in Amsterdam, Johan Heyns incidentally sat next to a black theologian whose name is now lost to posterity. He did not learn any theology from this man; this he was taught only by white men. He learnt from the black man to celebrate the Eucharist with hands in other colour skins touching the elements. That this was possible was a massive insight, withheld from him in his home country. It also made him personally vulnerable when he went home to tradisional prejudices between races. He was in line to get hurt.

Heyns growing fond of Renée Spamer was more traditional from an Afrikaner point of view. When he was a student in Pretoria his professors might not have been very theologically context-orientated, but they did take care to imprint on the young male minds (and bodies) in their classes a few styles befitting a Dutch Reformed minister: a young man training for the ministry is to acquaint himself with a woman preferably trained in social work. This perpetuates a tradition of putting pressure on missionaries who came to South Africa during the nineteenth century to marry women who would be useful on the missionary station as a source of free manual labour.

Spamer, however, was not a fully traditional young woman. She met Heyns in 1949 when he came to Pretoria for theological training and she to be trained as a social worker. When he left for Amsterdam for further study, she took up a job in a Nestle factory in Switzerland not only to be near her fiance, but also to explore a wider world during a time when very few women of her peer group ventured into such expansion. They knew 
1954, months, years, before he got his first call to a congregation in 1956. Ysterplaat housed very poor white people, refugees from the droughtstricken farms. Here Heyns laboured for six years, searching his heart for the right words to tell people with little formal education about soteriology and christology.

The call to Rondebosch congregation in 1962 came as a liberation to his intellectual needs. Heyns abandoned a refugee ministry to minister to the yuppies of the 1960s. This congregation not only housed the students of Cape Town University and many of their lecturers; it also served an elitist township in which the Verwoerds, the Vorsters and the Bothas lived when they were law-making in Cape Town. From here it was a small and almost natural step to being called as a lecturer to the Dutch Reformed seminary at Stellenbosch University. Johan Heyns and his previous classmate, Nico Smith, were called simultaneously to the seminary in 1966 . These were not positions to apply for: one waited to hear from the curatorium of the church whom they had appointed to perpetuate the values and teachings they regarded as important for the church.

Nico Smith's conversion at European hands occurred only at the end of the 1960s. Johan Heyns and Willie Jonker had gone to Europe twenty years earlier, in 1951 directly after their initial theological studies; they came back as white "liberals". However, after his final year with the class of ' 51 , Nico Smith spent 1952 preparing for the ministry, and 1953 doing a Masters' Degree in Sociology with Geoff Cronjé. At this stage Smith was convinced that Cronjé's theories on the biological and cultural differences between races as a rationale for separate development, were legitimate and moral. In 1969/70 then, almost two decades after his "liberal" classmates Heyns and Jonker, and after he had already taught for three years at the seminary in Stellenbosch, Smith went to Europe for his doctoral studies.

Smith's socio-political conversion in Europe is another story. Suffice is to say that, back in South Africa, the 1970s proved to be hard years for Smith in terms of racial consciousness. His newly awakened consciousness targeted, first of all, the Broederbond, a fraternity in solidarity with Afrikaner leadership. On the one hand this fraternity needed to be admired for the loyal empowerment of its inmates, but during the early 1970s Smith suffered a growing concern about the exclusivity of this empowerment and the Bond as a hurting machine towards blacks.

Incidentally, the one person towards whom Smith could voice his discomfort with the Broederbond, was Johan Heyns. Heyns took the typical "liberal" position, arguing for continued identification with Afrikaners, including the Broederbond, in order to make the racial attitudes of the 
including the Broederbond, in order to make the racial attitudes of the inmates more flexible. Smith, on the other hand, eventually abandoned the romantic ideals of such an identification in favour of a more unsafe position of confrontation. Heyns was concerned that confrontation would cause the people to close up their ears; Smith's concern was that identification would lead him to conform and eventually to an inability to voice criticism.

Both men then fearing not to be heard, Heyns chose for full identification by taking up the professorship in Dogmatics at the University of Pretoria in 1971; Smith chose for confrontation when he walked out of the Broederbond in 1973 and resigned his post as professor in Missiology at the University of Stellenbosch to become a minister of the black Dutch Reformed Church in Mamelodi in Pretoria.

What was Johan Heyns teaching his students at the University of Pretoria during the 1970s and 1980s while Nico Smith was burying the victims of political violence a few kilometers away? What did Heyns discuss with Carel Boshoff over tea times, his former classmate of ' 51 , then his colleague and professor in Missiology, while Heyns himself was under constant suspicion from a majority of white Dutch Reformed ministers of moving too far to the left?

For 22 years as professor of Dogmatics at Pretoria University, Heyns followed the path of critical identification he had lain upon himself, both inside and outside the classroom. He critically identified with the Dutch Reformed Church's racial policies, which developed from a document Ras, volk en nasie (1974) in which the church's identification with segregated development was obscured by rational distinctions between "volk" and "nation", into Kerk en samelewing (Church and society, 1986) where, in line with male rationality, apartheid was redefined in the light of advanced rational rereadings of the Bible and the human misery apartheid caused, underplayed. With his knowledge of national and international church political scenes, and his expertise in dogmatic formulation and human persuation, Heyns played a major part in formulating and selling these policies.

Through his performances at commissions, synods and meetings both locally and abroad, Heyns not only "liberally" identified with the racial policies of the Dutch Reformed Church and the developments thereof, he also critically identified with a special branch of Reformed dogmatics. This teaching acknowledged the knowability of God only insofar as He has revealed Himself in the Bible. In the Bible this branch of Reformed theologians found a God who was a creator and provider, the fully Other who can only be understood through the reported words of his incarnation, 
Jesus Christ. Heyns was critical of Reformed images of God on certain minor points, but on the whole Heyns' God was elective and aloof as the local male and white church preferred Him at that stage. This later led to some misunderstanding and intolerance between Heyns and liberation theologians who redefined God in terms of their human experience of being oppressed and who accentuated God's human side in solidarity with all marginalised people without exception or election.

The confidence with which Heyns proclaimed God to his students and the confident way in which he explained the church's dogmas to them, discomforted some of these students. However, even those students who considered Heyns' teaching to be too modernist and who themselves developed towards a post modernist position in academic life, nevertheless blaimed their own interest in theology on Heyns' inquenchable enthusiasm for the subject he taught.

While Heyns was enthusiastically engaged in mental exercises with his students in the 1970s and early 1980s, he was not well-known to the press nor to the public. Local political scientists did not take notice of him as a possible spokesperson for the Dutch Reformed Church on political issues. Then Heyns was elected moderator of the General Synod of the Dutch Reformed Church in 1986. And Heyns was to learn that in this position men get hurt. He had eight more years left to live and half of them he spent as moderator, moderating to the right and to the left during a time when the correct or rather the right (meta-)word at the right time could no longer move men to the middle when they were feeling the power slipping from their hands. In 1987 the rightwingers seceeded and formed the Afrikaans Protestant Church.

Heyns' failed efforts to keep everybody in the shed left him heartbroken, which contributed to suspicions amongst the moderate liberals that they did not know where they stood with him. They noticed that when Heyns spoke to an audience which made rightist noises, he would try to convince them that all the people in the Dutch Reformed Church had a common enemy in communism and that he could lead them in this war. On the other hand, when he picked up a need to express himself more liberally, for instance on overseas visits, he explained to his audience that the type of segregated development he was supporting, aimed at the wellbeing of blacks in particular. This caused Nico Smith to view Heyns as a moralist without moral courage. Political scientist Willem Kleynhans compared Heyns with B B Keet and Ben Marais and found Heyns' contribution to the changing of racist attitudes in the Dutch Reformed Church to be minimal. 
While some people were waiting for Heyns to ripen the church for change, Heyns was planting the seeds of political change in the hearts of his students. He prepared a younger generation of ministers for the political reforms of the 1990s by projecting his policy of critical identification on them. Cornel du Toit experienced him to be a contextual genius who led his students and his church just enough ahead not to lose them. Nico Smith also regarded Heyns as contextual - only he did not experience Heyns' context to be Africa.

Johan Heyns empowered many people to participate in political change in South Africa; he also hurt many people personally. In spite of the overall impression of goodwill he displayed towards people, he was known for his sharp tongue which left scars and unforgivingness in the minds of people who sat with him on commissions and who engaged in academic discussions with him. Johan Heyns was badly hurt himself, especially during his term as moderator. Insulting phone calls and letters became part of his daily communications with people, the people he wanted to please. They made him cry, but only momentarily, because he believed, they say, blindly in the goodwill of God and people, both with whom he spent a lot of time.

And then there were people who were jealous of Johan Heyns, who envied him the recognition he did receive from the church. Johan Heyns achieved in the church what he had originally aimed at, and that was to swerve their thinking somewhat to the middle of the political scenario of South Africa. And there were people who were annoyed at this success.

Who shot Johan Heyns on 5 November 1994 and why? Theories abound. He ventured too far to the left, one theory claimed. Against this it is argued that Heyns had already retired (since 1993) when he was killed and at that time exercised little direct influence on church policy. A second theory was that Heyns died for having promoted the constitution of a Truth and Reconciliation Committee, the fruits of which we see today. In support of this theory the observation is put forward that at the time when the Commission was actually becoming a reality, reports were spread by the press that Heyns was killed by a jealous husband, thereby rendering his support to the Commission ineffective. Also, of course, Heyns had inside information on many state related matters and persons because of his close connections with the previous government. A Truth and Reconciliation Commission might have placed him under an obligation to share this knowledge.

Other rumours then claimed that Heyns was not killed for political reasons at all but that somebody with a personal grudge against him had 
him killed. It might have been the husband of a woman whom Heyns consoled when she was in distress over her marriage. It might have been a person forcedly removed from a piece of land when its wealthy owner, Johan Heyns, sold the land to somebody else.

The story of Johan Heyns does, of course, not have an ending. It continues forever into the future, as long as he generates stories. We may, however, temporarily place an ending to this story of Johan Heyns and an ecclesiastical hurting game by loosely quoting Willie Jonker, the man who confessed the Dutch Reformed Church's sin of apartheid and who, on another occasion, confessed unofficially and with a sincere heart: Nobody could hurt me more than my dear mother the church, and her men.

\section{NOTES:}

1 They were Hennie Theron (prof, APK), Frans van Staden (prof, APK), Christo Delport, Geo Wolhuter, Johan Heyns (prof, Pretoria), Andrew Hofmeyr (prof, Witsieshoek), Japie Scholtz, Murray Janson (prof, UNISA), Koos van Dyk, Karel Struwig, Willie Jonker (prof, Stellenbosch), Deon de Villiers (prof, Witsieshoek), Carl Boshoff (prof, Pretoria),. Nico Smith (prof, Stellenbosch) and Jan van Rooyen.

2 In his book Die liberale rigting in Suid-Afrika, 'n kerkhistoriese studie I, Stellenbosch 1951, x.

3 Interview with Nico Smith, 20 Febr 1996.

$4 \quad$ Interviewed on 19 February 1996.

$5 \quad$ Interviewed on 30 July 1996.

6 Interviewed on 10 February 1994. This interview concentrated on Willie Jonker's own contribution and his references to Johan Heyns were incidental.

$7 \quad$ Interviewed on 29 July 1996.

8 Interviewed on 20 February and 30 July 1996.

9 Much of this paragraph is based on Sharon O'Brien, "Feminist theory and literary biography" in Contesting the subject (Essays in the postmodern theory and practice of biography and biographical criticism, Edited by William $\mathbf{H}$ Epstein), West Lafayette, Indiana 1991, 123-133.

10 Another important source for the methodological ideas expressed in this paragraph is Annalies van Heijst, Longing for the fall, Kampen 1995. 
11 Apart from the oral sources, this story was also influenced by P G J Meiring, "'n Huldigingsartikel: Johan Heyns - Man van die kerk", Skrif en Kerk 15/1 (1994), 177-184, en Rebecca de Saintonge, Outside the gate. The story of Nico Smith, London 1989. 